\title{
Realia as a Media to Improve the EFL Learners' Achievements in Descriptive Writing
}

\author{
Sumarsih $^{1}$ \\ ${ }^{1}$ Faculty of Languages and Arts, Universitas Negeri Medan, Indonesia

\begin{tabular}{ll}
\hline \hline ARTICLE INFO & ABSTRACT \\
\hline \hline
\end{tabular} \\ Article history: \\ Received March 27, 2019 \\ Revised April 28, 2019 \\ Accepted June 02, 2019

\section{Keywords:} \\ Realia, \\ EFL Learners, \\ Writing, \\ Descriptive Paragraph \\ Clonflict of Interest: \\ None \\ Funding: \\ None \\ Corresponding Author: Prof. Dr. Sumarsih, M.Pd., English and Literature Department, Faculty of \\ Languages and Arts, Universitas Negeri Medan, Jl. Willem Iskandar Pasar V - Kotak Pos No. 1589 - \\ Medan 20221, Indonesia. Tel: 62-812-604-7395. E-mail: isih58@yahoo.com. \\ Copyright (C) Association of Language Teachers in Southeast Asia. \\ All rights reserved

\section{Introduction}

\subsection{The Background of The Study} \\ In learning the English language, there are four skills should be taught to students. They are speaking, \\ listening, reading and writing. In practice, learning the lessons taught writing after speaking, listening and \\ reading. But this does not state that learning writing is not important. In fact, since writing was a very \\ important lesson learning why writing is taught after the third important element is taught and writing also is \\ the very difficult subject for the students. It is related to Oshima and Hogue (1999) that writing, particularly \\ academic writing is not easy. It took study and practice to develop this skill. For both native speaker and new \\ learners of English, it is important to note that writing is a process, not a "product". This means that a piece \\ of writing, whether it was a composition for your English class or a lab report for your chemistry class is \\ never complete; that is, it is always possible to review and revise, and review and revise again. \\ Writing was a very important capability for being owned by students, writing is also an excellent \\ communication tool. Through writing, each person will be able to convey feelings, ideas, and announcements \\ to others. Sharples (1999) actually, writing is an opportunity; it allows students to express something about \\ themselves, explore and explain ideas. Student can convey their ideas in their mind by organizing them into a \\ good text so that the others know them and they can think critically. Therefore, learning is very important for \\ improved writing in particular learning of English in Indonesia because the writing is a process of \\ transformation of thoughts and ideas into tangible forms of writing. In addition, many people choose writing \\ as a means of effective and efficient communication of information to be conveyed in some ways like posting \\ letters, business letters and important information in a company's product.
}


In the Kurikulum Tingkat Satuan Pendidikan (KTSP) (Mulyasa, 2006) syllabus of junior and senior high schools curriculum require students to be able to write some kind of genre in writing. They are narrative, recount, descriptive, report, explanation, analytical exposition, hortatory exposition, procedure, discussion, reviews, anecdote, spoof, and news items.

Based on the above, the descriptive text is one genre that must be mastered by students in learning English. And theoretically, according to Evawina (2010) descriptive paragraph is a paragraph vividly portrays a person, place, or thing in such a way that the reader can visualize the topic and enter into the writer's experience.

In fact, not all students are able to write descriptive paragraph properly and in accordance with the existing elements in the descriptive text. Based on the researcher's observation, $70 \%$ of students were unable to write a descriptive paragraph. Teachers of English already taught the material to students well but the students still had the problem in writing descriptive paragraph. In addition, the researcher also had looked the teachers of English language teaching by lecture, and then asked the students to write descriptive paragraph individually and there is no media.

From the above, student's ability to write descriptive text was very less because the learning methods that has been adopted by teachers of English language has been a method that does not fit anymore in this day because it reduced the interest and liveliness of the students in the learning process so that students were bored and did not want to continue learning as they should.

Because of that it is needed to improve the student ability in writing descriptive text by using media and the media that is used in this study is Realia. Realia can increase the students' ability in writing descriptive text and will be interested in learning English because using realia that is making a connection between objects and language.

By using Realia will be expected to enhance students' skills in writing descriptive text properly and in accordance with the existing elements in the descriptive paragraph.

1.2 The Research Question

Based on the background of the study, the research question was formulated as follows: "Is the students' achievement in writing descriptive significantly improved when they are touch by using Realia?"

1.3 The Objective of The Study

In relation to the problem, the objective of the study is to investigate and to find out the improvement of students achievement in writing descriptive text by using realia.

\section{Review of Literature}

\subsection{Theoretical Framework}

The basic concept of the study should be made clear from the beginning. Theoretical framework aims to give clear concept to the application of TPS in this study. The researchers of this thesis planed investigate the improvement of applying TPS on the student's achievement on writing descriptive paragraph. It is essential to describe some terms that related to this research to prevent misunderstanding between the writer and the reader.

\subsubsection{Achievement}

Travers (1970) states that achievement is the result of what an individual has learned from some education experience. Additionally, Yelon, Weinstein, and Weener (1977) expressed that achievement as the successfulness of individual. Furthermore, Tinambunan (1988) defines achievement as the students' grasp of somebody of knowledge or proficiency in certain skills.

Based on the opinions above, it can be concluded that achievement is the result, the successfulness, the extent or ability, the progress in learning education experiences that the individual indicates relation with his/her educational learning. Achievement concerns with what someone has actually learnt whereas aptitude is the potential for learning something. In other words, achievement is a success in reaching particular goal/status or standard, especially by effort, skill, courage, and so on.

\subsubsection{Writing}

Writing is a process of formulating and organizing ideas in right words to deliver the aim and present them on a piece of paper. According to Jones in Cooper and Odell (1977) writing is synonymous with discourse, and discourse will be discussed in terms of its aims, it relate to the function of language, and in terms of its feature, which are the separate elements, devices, and mechanism of language.

On the other hand, Reinking, Hard and Osten (1993) state that writing is a way of communication and of course communicates all the time. And then Deporter and Heracki (2002) explain that writing is a whole brain activity, which use bright brain side (emotion) and left-brain side (logic). Although right and left-brain sides are used in writing, right brain side has a big position because it is a place, which appears new ideas and emotion.

SALTeL Vol. 2, No. 2, July 2019: $63-71$ 
From the explanation above, we can state that writing is a whole brain activity to formulate and organize ideas in right words to deliver and communicate the aims to the reader and present it on a piece of paper.

2.1.3 Descriptive Text

A descriptive text is a piece of writing that is intended to convey meaning to the reader through sensory details and provides image to the reader Sanjaya, Mokhtar and Sumarsih (2015). Additionally, descriptive text is a paragraph may be defined as a group of sentences that are closely related in thought and which serve one comment purpose often used to describe what a person looks like and acts like, what a place looks like, and what an object looks like. Furthermore, Pardiyono (2007) state that description paragraph is a type of written text paragraph, in which has the specific function to describe about an object (living or non-living things) and it has the aim that is giving description of the object to the reader clearly.

From the definition above, it can be concluded that description paragraph is a paragraph that describes a particular person, place or event in great deal. Description writing vividly portrays a person, place, or things in such a way that the reader can visualize the topic and enter into the writer's experience. It is a way to enrich others forms of writing or as a dominant strategy for developing a picture of what something looks like.

Furthermore, Jolly (1984) assert there are five types of descriptive writing paragraph. They are:

a. Describing Process

Describing a process not only explains how something is done, but also explains why it is done and what is needed to complete the process.

b. Describing and event

To describe an event, a writer should be able to memorize and remember what happened in the event. Supposed the writer will write about Tsunami that is happened in Japan. In this case, he / she has to explain all details related to the event, so that the readers can imagine the real situation and condition.

c. Describing a personality

In describing a person, the first thing that we do is recognizing his/her individual characteristics. We need to describe people occurs fairly areas of physical attribute (hair, eyes), emotional (warm, nervous), moral attributes (greedy, honest, worthy, trust), and intellectual (cleverness, perception)

d. Describing a place

Presenting something concrete is the way to describe place, for example: a home, a hospital, and school.

e. Describing an object

To describe an object accurately is done by providing the physical characteristics of the object such as the color, form, shape, and so on.

\subsubsection{Part of Descriptive Text}

Pardiyono (2007) maintain that three parts of descriptive, they are (1) Communicative purpose, that is to describe an object (human and non-human). (2) Rhetorical structure, there are two parts of rhetorical structure a) identification, that is statement that consist of one topic to describe; b) description, that is consist of the detail description about object that identify in identification, and (3) Grammatical patterns, it is needed to understand that in descriptive paragraph, declarative sentence is used and using present forms.

\subsubsection{Media}

According to Arsyad (1997) the definition of media is intermediary or delivery massage from the deliverer to the receiver of the message. It means that media is the intermediary to say something. It is related to Gerlach and Ely (1971) say that if the media understood the outline is human, material or events that establish the conditions that make human beings acquire knowledge, skills and attitudes. Media also has the advantage in teaching and learning process.

Based on the definition above, Media is a tool that is intermediary for saying something or delivers something from the deliverer to the receiver.

According to Kemp and Dayton (1985)

1) Lessons more interesting

2) Long learning time required can be short

3) Quality of learning outcomes can be improved

4) Positive attitude towards students what they learned and the learning process can be enhanced.

5) Teacher's role may change towards more positive.

\subsubsection{Realia}


According to Adrianne and Jordan (2004) the word 'Realia' sounds vaguely Latin. Realia means using real items found in everyday life as media to teaching English. Using realia helps students to make English lessons memorable by creating a link between the objects and the word or phrase they represent. Realia breathes life into new vocabulary, the chances of the students remembering the new words have taught those increases, and automatically can write or share about the object or to provide experience on which to build and to provide students with opportunities to use all the senses in learning. E.g. take the word biscuit: the probability of remembering it becomes much higher after experiencing the taste, touch and smell of the object. Realia does not have to be limited to food or drink. Timetables, tickets, newspapers, clothes or in fact any object can think of can be used as a teaching media.

While using realia in the classroom is not always possible, it is usually the best choice if the students are learning all they can do about topic. If the real thing is not available, the teacher must move down the continuum from the concrete (real thing) to replica such as a model, to a semi concrete object such as a photograph or illustration. Hoeever, each move down the continuum causes the loss of some sensory information that could be helpful in comprehension.

\subsubsection{The Characteristic of Realia}

There are five characterization of realia, which are used by teachers in the classroom according to Brown (2000). They are: 1) Non-repetitive, realia exercises do not repetition for their value. In fact any particular activity of this type is often just done once, or possibly twice. This is not just because their value does not lie in repetition, but also because by their very nature they are time-consuming activities. In writing application, non-repetitive is done too. The students just write once about one object and without repetition. The students tell the truth about the object and have the saves time so the students can manage their time to write the main point of the objects too. 2) Meaningful, realia has been developed in the expectation that the situation will engage the students; the result should be discussion that is lively and even earnest. The objects told by the students are meaningful and directed to point of the topic. The students do not just write what they think in their mind, but know what is the word must say structurally. 3) Whole practice, realia concentrate on small segments of behavior. The students do not practices to improve their writing skill. They must learn and have behavior to study more all about the objects. 4) Direct, at this stage, the students make efforts to practice the terminal behavior itself-actually, using language in stimulations of real stimution. Stimulation is important in this respect. When the students write in front the class, directly they will be stimulated and tell about the object of realia. 5) Free, in realia practice, the students are allowed to express their ideas, thoughts, feelings, in line with their whishes and capabilities. The teacher's role is not to insist that any particular language item is used. The students are free to write what they think in their mind meaningfully, like they want to tell about the color, model, taste, etc.

\subsubsection{The Steps of Implementing Realia}

The steps in implementing of realia according to Adrienne and Jordan (2004) are: 1) Identifying Opportunities to Use Realia, be aware of opportunities to include realia in lessons as you plan reread any stories to be read aloud or used for reading instruction to identity vocabulary that may be unfamiliar to the students and locate realia that will be helpful to their understanding. The students try to find the words are difficult before writing in front of the class based on the object. For example, they have note of the difficult vocabulary and to find the meaning of the words to make easier in writing. 2) Collecting Data, begin to collect items that can be stored in the classroom and organize them so that they can be easily accessed for instruction. The students try to find the objects, which are used in writing in front of the class. They must know what type of the object or how much it is. They know all of things about the objects. 3) Building a Library of Realia, after knowing all of things about the objects, the students have many vocabularies. For example is fruit. They know what are the English of warna (color), bentuk (model), batang (stem), and daun (leaf). They do not know before, but after learning using realia they like building a library of realia by them. 4) Using Fields Trips as Realia, if it is too large to move and the students' learning would benefit by experiencing it, take a field trip. Give students the opportunity to really understand what they are studying. The students will be spirit to write after look at the object directly. But for note here, if it is the object impossible brought into the class like building of school, Borobudur temple, etc. the writer wants to emphasize that the writer does not use this step in implementing realia in teaching learning process. The writer is focus in the classroom only.

2.1.9 The Advantages of Using Realia

Realia as media are useful in teaching and learning process. Here, some the advantages of realia:

1) Using realia stimulates the mind, and is one way of encouraging creativity by involving the senses. The students will be stimulated directly after looking at the object and starting to write what are in their mind.

2) Realia saves time, as recognition of an object is immediate and so cuts out of the need for lengthy explanations and drawing funny pictures on the boards. Elicitation becomes much easier and holding up 
the object with a raised eyebrow will usually result in the desired word being spoken. The students speak spontaneously after getting and knowing about the object without waiting for some steps. And it makes the teaching learning process on time.

3) Realia breathes life into new vocabulary, and the chances of students remembering the new words have taught them increases. For eample they have known about the object, automatically they will find the difficult words and try to know the traslation.

4) Realia makes the learning experience more memorable for learner. The students will remember about their learning aafter speaking in fron of the class. Because they try to find the words by themselves and it is depends on them to speak what they want to speak about the objects.

\section{Research Method}

3.1 Research Design

This research was conducted as an action research procedure since involved a substantive act with a research procedure to find the improvement. Stringer (2007) maintains that action research is systematic approach to investigation that enables people to find effective solutions to problems they confront in their everyday life. Action research focused on specific situations and localized solutions. Action research provided the means by which people in schools, business and community organizations; teachers; and health and human services may increase the effectiveness of the work in which they are engaged.

The classroom action research is dynamic process. Evawani (2010) states that an action research process involve a cyclic sequence. There are four steps in cyclic sequence. 1) Plan: In this step, the researcher finds the problem of students and plans to do what activity will be applied. 2) Action: The plan, which has been designed, is done in this phase. The media of improvement is applied. The action will be continuously done, until the researcher finds the improvement. 3) Observation: this step is the effect of the actions that have been done. During the learning process, the collaborator observer what the students do. 4) Reflection: the evaluation of action, which will be applied. It can overcome the problems that appear in previous steps/cycle. 3.2 The Subject of Research

The subject of this research was the seventh grade (VII), which consists of 32 students. The reason for choosing this class was because the writer found some problems in students' writing achievement, especially in writing descriptive text.

\subsection{The Instrument for Collecting Data}

Quantitative data were collected through evaluation sheet and questionnaire, which administrated by the researcher and qualitative data were collected through observation sheet and interview sheet. Observation sheet will be used to identify all the condition that happened during the teaching learning process including teacher, students and the context of situation that were done by the collaborator, interview sheet will be used when the writer want to identify the problems occurred in the learning process and questionnaire as the personal records which usually taken by the writer written up daily.

\subsection{The Procedure of the Research}

Before doing the research procedure, the consistent choosed one team administered observation and get the license research from the school and orientation identified the basic knowledge of students about writing descriptive text in the school. The procedure of data collection of the study was conducted within two cycles. First cycle have 3 meetings; second cycle have 3 meetings, so there was 7 meetings in the action research included the meeting in orientation test. Each meeting includes four stage namely planning, action, observation, and reflection.

\section{CYCLE 1}

In the first Cycle, the writer will conduct three meetings, Cycle 1 will conduct based on the problems will find in the orientation test and observation sheet. In this cycle the students writing skills will be measured and the problems in the writing will be analyzed.

\section{PLANNING}

Planning is arrangement for doing everything that will be needed in teaching learning process.

The activities of the researcher:

a. Prepare the lesson plan.

b. Prepare students in a class

c. Prepare the questionnaire, interview sheet and observation sheet.

d. Prepare and design the worksheet, and quiz as evaluation for them.

e. Prepare the facilities and media that will be used.

f. Determine a collaborator who helps the researcher to do the research and to observe the activities.

Plane and design the application media and procedural of teaching learning writing media Realia

\section{ACTION}

Action is the process of doing and implementing of plan. So in this phase, everything will have been planned. 1. Opening: the teachers open the class; greet the students and deliver the objective of the study. 
2. Main: a) The researcher explains the kinds of writing briefly that will be studied, namely descriptive text by using media Realia invite the students to give the question about the material if they are not understood. b) The researcher gives the example of the procedure text, and then explains the social function, generic structure, and language feature. c) Ask them to write a procedure text related to their pet or home individually as a quiz.

3. Closing: a) The researcher deliver the conclusion about the material. b) The researcher give the questionnaire to the students and the students answer it. c) The researcher asks the students' difficulties about the topic discussion.

\section{OBSERVATION}

Two others researchers as the collaborators observe every action, situation and the students' attitude that will be happened during the teaching and learning process by using the observation sheet.

\section{REFLECTION}

Reflection is the feedback process from the action that has been done. a) The researcher and collaborator collect the answer sheets of the quiz of the students, observations, interview, and questionnaires. b) The researcher and the collaborator evaluate the result of observation, quiz and questionnaire.

The writer and collaborator decide the following action that revise the plans base on the weakness of the first cycle and go to Cycle 2.

3.5 Scoring the Test

In scoring the test of this research, the researcher applied the writing scoring technique that related to Refandi (2006) the writing scoring technique is the question and the answer are given to the students in writing form. And this technique applied the five indicators of the writing descriptive text. The five indicators are; content, organization, vocabulary, language use and mechanics.

\section{1) Content}

Scoring the content is based on the students' ability to write their ideas and information in the form of logical sentences.

\section{2) Organization}

Organization refers to students' ability to write their ideas and information such a good logical order to topic and supporting sentences are clearly stated.

3) Vocabulary

Vocabulary refers to the students' ability in using word or idiom to express idea logically. It also refers to the ability to use synonym, antonym, prefix, and suffix exactly.

4) Language Use

Language use refers to the students' ability in writing the sentence, simple, complex and compound sentence correctly and logically. It also refers to the ability to use agreement in the sentence and some other words such as noun, verb, and time signal.

5) Mechanics

Mechanics refer to the students' ability to use words appropriately and function correctly, such as punctuation and spelling. Paragraph and text can be read correctly.

For all components, students got the score 100 points, in which, the score for content is 30 point, organization is 20 point, vocabulary is 20 point, language use is 25 point, and mechanism is 5 point.

\subsection{The Technique of Analyzing the Data}

The study applied quantitative and qualitative data. The qualitative data was analyzed by using questionnaire, interview and observation sheets, which described the improvement of the students' achievement on writing descriptive paragraph. The quantitative data was collected and analyzed by computing the score of writing test.

Formula for mean:

$$
\begin{aligned}
& \text { Xfi }=\frac{\sum \chi}{N} \quad X 100 \% \\
& \text { In which: } \\
& \text { Xfi } \quad=\text { The mean of the students' score } \\
& \sum \chi \quad=\text { The total score } \\
& N \quad=\text { The number of students }
\end{aligned}
$$

The score percentage of each cycle will be calculated by using this formula:

$P=R \times 100 \%$

In which:

$\mathrm{P} \quad=$ the percentage the students who get the score 75

$\mathrm{R}=$ the number of the students who get score 75 to up 
$\mathrm{T}=$ the number of students who do the test.

\section{Data and Data Analysis}

4.1 Quantitative Data

4.1.1 Writing Score

Table 1: Comparison Score of Students' Writing Evaluation

\begin{tabular}{|c|c|c|c|}
\hline \multirow{3}{*}{ Type of Score } & Evaluation I & Evaluation II & Evaluation III \\
\hline & M1 & M4 & M6 \\
\hline & \multicolumn{2}{|c|}{ Cycle I } & Cycle II \\
\hline Lowest Score & 60 & 70 & 75 \\
\hline Highest Score & 80 & 85 & 90 \\
\hline $\mathrm{N}$ & 32 & 32 & 32 \\
\hline \multicolumn{4}{|l|}{ Note: } \\
\hline = Meeting & & & \\
\hline$=$ Number $\mathrm{C}$ & nts & & \\
\hline
\end{tabular}

From the table above, it was seen that students' score kept improving. In writing evaluation I, the lowest score was 60 and the highest score was 80. In writing Evaluation II, the lowest score was 67 and the highest score was 88 whereas in the last writing evaluation, the lowest score was 81 and the highest score was 94 . It showed the significant improvement in students' writing descriptive paragraph.

The improvement of students' score in writing descriptive paragraph through realia also can be seen from the mean of the students' score in every writing evaluation.

Table 2: The Improvement of Mean Scores of Students' Writing

\begin{tabular}{cccc}
\hline Meeting & & Total Score & Mean \\
\hline Evaluation I (Cycle I) & I & 2121 & 66,28 \\
\hline Evaluation II (Cycle I) & II & 2456 & 76,75 \\
\hline Evaluation III (Cycle II) & III & 2784 & 87,00
\end{tabular}

The mean of the students' score in the first meeting was the lowest of all meetings. In the last meeting, the students' score improved. From the data analysis, the mean score of the students' writing increased from 66,28 to 87,00 . It means that the ability of students in writing descriptive paragraph was improved.

In this research, the indicator of successful in writing descriptive paragraph was if $75 \%$ of students have got score up to 75 in their writing evaluation because the English passing grade at the school was 75 .

Table 3: The Percentage of Students' Writing Descriptive Paragraph

\begin{tabular}{ccccc}
\hline Evaluation & Cycle & Meeting & Students who got score 75 up & Percentage \\
\hline I & I & I & 3 & $9.38 \%$ \\
\hline II & I & IV & 15 & $46.87 \%$ \\
\hline III & II & VI & 32 & $100 \%$
\end{tabular}

In writing evaluation I, there were 3 students who got point 75 up. The percentage of students' achievement in descriptive paragraph kept increasing when realia was applied. In the first cycle $9.38 \%$ students got points 75 up whereas in the second cycle $100 \%$ students who got points 75 up. It can be concluded that realia worked effectively and efficiently in improving students' achievement in writing descriptive paragraph.

\subsubsection{Questionnaire}

From the result of questionnaire, it can be found out that realia can improve the achievement of students because from the data no one of the students fill in disagree and strongly disagree then no more than 4 students fill in the neutral. So most of the students fill in agree and strongly agree. It meant that this realia was very good for the students.

From the data taken from questionnaire sheet I statement 1 until statement 8 , the percentage of strongly agree was $44,21 \%$, agree was $47,86 \%$, neutral was $7,93 \%$, disagree and strongly disagree were $0 \%$. So, from this questionnaire data, students were very interested and enjoying the realia in teaching learning process especially in writing descriptive paragraph. 
Besides that, from the data that was taken from the questionnaire sheet 2 it can be found in the first statement that the percentage of student who chosen A was $58,54 \%$, B was $14,63 \%, \mathrm{C}$ was $19,51 \%$ and D was 7,32 $\%$. It means that most of students had learned to work to gather from this realia. So they were active in teaching learning process. Then, from the statement 2 the student who chose A was $53,66 \%$, B was 24,39 $\%, \mathrm{C}$ was $12,19 \%$ and $\mathrm{D}$ was $9,76 \%$. It means that most of students had learned about pair accountability and pair responsibility. In additional, from the statement 3 the student who chose A was 78, 05\%, B was 7, $32 \%, \mathrm{C}$ was $9,76 \%$ and $\mathrm{D}$ was $4,88 \%$. It means that most of students in this research had learned to produce something alone.

From the all questionnaire data, it can be concluded that the students were very interested and enjoying the realia and the students were not only improving their achievement in writing descriptive paragraph but also improving their teamwork, responsibility and self-confidence.

\subsection{Qualitative Data}

The qualitative data were taken from observation sheet, questionnaire sheet and interview that gained within two cycles.

\subsubsection{Observation Sheet}

From the result of observation sheet, it can be concluded that teaching learning process by applying realia run well. The situation of teaching learning process was comfort, lively, and enjoyable. Because from the data that was taken from the first (I) meeting to the last (VI) meeting we can find out that the Note in the data got good and very good. It means the score in this data was just gotten from 3 to 4 .

So this realia created a good environment in teaching learning writing in which students became active in the process of writing, focus their mind to the teachers' explanation, and share in their team and pair and then finis in individually. In individually work, the students could improve their confidence to finish the work because they had discussed in team and pair.

\subsubsection{Interview}

From the interview data those were taken by the teacher and the students from the first meeting and the last meeting, the teacher was very interested because the students were very active and enjoyed with English but students ability in writing descriptive paragraph was not good enough and then the teacher did not have effort to improve it.

From the interview with the students in the first meeting, it can be found out that the students very interested with English and most of the students like to write descriptive paragraph, because from 6 students that the writer interviewed said like. So from this data we can conclude that most of the students like to write the descriptive paragraph. That is why it is needed to improve their achievement in writing descriptive paragraph by the application of realia.

From the second interview that was taken from teacher, it can be find out that the application of realia in teaching learning process especially in writing descriptive paragraph was very helpful to improve the ability of students in writing descriptive paragraph. And according to the teacher this method is very good because can make the students became active and enjoy the lesson.

Furthermore, from the last interview that was taken from the students it can be fond out that most of the students like this method and the said that this method is very good to improve their achievement in writing descriptive paragraph because they could be active and enjoy the material. And from the 6 students, all of them said realia is very good and just one student said that it is very busy but the student also like.

So, from the entire interview, it can be concluded that realia is very good to improve the students' achievement in writing descriptive paragraph at SMP Grade VII-4 semester one and two.

\section{Conclusion and Suggestion}

\subsection{Conclusion}

Having analyzed the data that have been presented in the previous chapter, it was found that average scores of students in every evaluation kept improving. It can be said that there is a significant improvement on the students' achievement in writing descriptive paragraph by applying the application of Realia. It can be seen from the improvement of mean of students' score, namely: the mean of first evaluation $(66,28)$ increased to the mean of second evaluation $(76,75)$ and the mean of third evaluation $(87,00)$. The score continuously improved from the first evaluation to the third evaluation. Observation result showed that the students gave their good attitudes and responses during teaching and learning process by applying the application of Realia. Questionnaire and interview report showed that students agree that the application of Realia had helped them

SALTeL Vol. 2, No. 2, July 2019: 63-71 
in writing descriptive paragraph. it can be concluded that the application of Realia significantly improved students' achievement in writing descriptive paragraph.

\subsection{Suggestion}

The result of this study showed that the application of Realia could improve students' achievement in writing descriptive paragraph. In relation to the conclusion above, some points are suggested, as follow:

1) The English teacher are suggested to use Realia as teaching method to stimulate the students' learning writing spirit in teaching writing process.

2) For the readers who are interested for further study (university students) related to this research should explore the knowledge to enlarge the understanding about how to improve students' achievement in writing and search another reference.

\section{References}

Adrienne and Jordan. (2004). Fifty Strategies for Teaching English Language Learners, New Jersey: Pearson Education.

Arsyad, A. (199). Media Pembelajaran. Semarang: Raja Grafindo Persada.

Brown, D. H. (2000). Principle of Language learning and Teaching, pearson Education Company.

Cooper, Charles R., and Odell, Lee. 1977. Evaluating Writing. United States of America: The National Council of Teachers of English.

Deporter, B. and Heracky. M. 2002. Quantum Learning. Bandung: Penerbit Kaifa

Evawina S., Ervina. 2010. Thesis of Improving Students' Achievement on Writing Descriptive Paragraph through the Application of Student Team Achievement Division. Medan: State University of Medan.

Gerlach, V. G. And Ely, D. P. 1971. Teaching and Media. A systemmatic Approach. Englewood Cliffs: Prentice-Hall, Inc.

Jolly, D. 1984. Writing Task. New York: Cambridge University

Kemp, J. E. and Dayton, D. K. 1985. Planning and producting Intsructional Media (Fifth Edition). New York: Harper \& Row, Publisher.

Pardiyono. 2007. Pasti Bisa! Teaching Genre Based Writing. Yogyakarta: CV. Andi Offset.

Mulyasa, E. (2006). Kurikulum Tingkat Satuan Pendidikan. Bandung: Remaja Rosdakarya Offset Bandung.

Oshima, A. And Hogue. 1999. Writing Academic English; Third Edition. United State of America: Addison Wesley Publishing Company.

Refandi. 2004. Model Penilaian Kelas Kurikulum Tingkat Satuan Pendidikan. Jakarta: CV. Timur Putra Mandiri.

Sanjaya, D. Mokhtar, A.A. and Sumarsih (2015). The impact of personality (extroversion/introversion) on Indonesian EFL learners' essay writing achievement. Asian EFL Journal Professional Teaching Article, (87) 4-20.

Sharples, M. 1999. How We Write; Writing as Creative Design. London: Routledge.

Stringer, Ernest T. 2007. Action Research Third Edition. United State of America: Sage Publication Inc.

Tinambunan, Wilmar. 1988. Evaluation of Student Achievement. Jakarta: Depdikbud.

Travers, John P. 1970. Fundamental of Educational Psychology. Scranton, Pensylvania: International Textbook Company.

Yelon, Sthepen L., Weinstein, Grace W., and Weener, Paul D. A. 1977. Psycology in the Classroom. Tokyo: Mc Graw-Hill, Inc. 